\title{
BUONGIORNO, SIORA MASCARA!
}

\author{
ВАЛЕНТИНА СОБОЛЬ \\ Варшавський університет, Варшава - Польща \\ BUONGIORNO, SIORA MASCARA! \\ WALENTYNA SOBOL \\ Uniwersytet Warszawski, Warszawa - Polska
}

\begin{abstract}
STRESZCZENIE. Artykuł poświęcony jest ukraińskiej recepcji Wenecji-kolebki cywilizacji europejskiej. Podjęto próbę spojrzenia na Wenecję i Ukrainę przez pryzmat postępujących zmian, jakimi obecnie żyje cały świat. Karnawał, który odrodził się w Wenecji u schyłku XX wieku, skłania do rozmyślań o wyczerpywaniu się starego czasu, na zgliszczach którego już kształtuje się nowy świat... Nowy czas ukraiński. Nowy świat ukraiński!
\end{abstract}

\section{BUONGIORNO, SIORA MASCARA! \\ VALENTINA SOBOL \\ Warsaw University, Warsaw — Poland}

ABSTRACT. The investigation is devoted to the Ukrainian reception of the unanimously recognized cradle of European civilization, Venice. An attempt has been made to view Venice and Ukraine in the process of contemporary changes the world is involved in. The carnival, revived in Venice at the end of the $\mathrm{XX}^{\text {th }}$ century, rouses pondering over the depletion of old age and arising the new one... New Ukrainian age. New Ukrainian world.

$\mathrm{B}$ uongiorno, siora mascara!”, що означає „вітаю, сестро маско!”. Саме так у XVIII столітті у Венеції віталися під час карнавалів, коли до міста з оказії свята „Ля Сенса” (La Sensa), під час елекції дожів та зашлюбин їхніх дітей прибувало багато знаменитостей. А як з'явилися перші, а нині всесвітньо знані маски?

Легенда пов'язує цей факт із жінкою й сягає 1204 року, коли Енріко Дандоло (Enrico Dandolo) почав виганяти з підкореного Константинополя мусульманських жінок. Їхні прекрасні обличчя, сховані заслонами та масками, тоді чомусь нагадували кондотьєрові душі померлих.

Перша жінка, яка 1678 року здобула науковий титул в Італії, зокрема в Падуанському універстеті, була італійка — це Олена Лукреція Корнер Піскоріа.

А перша українська жінка в Падуї, правдоподібно, та, яка подарувада їй незрівнянні українські вишивки. Хоча перший український акорд на землі Вівальді - то студіювання в Падуї, але також і в Болонії, Венеції і навіть у Римі ${ }^{1}$ gente ruthenus, natione polonus Станіслава Оріховського Роксолана (1513-1566)2. Гуманістичні студії в Італії приваблювали його найбільше.

${ }^{1}$ Примітка. Саме в Римі Станіслав Оріховський Роксолан звернув на себе увагу одного 3 кардиналів, при дворі якого перебував певний час.

${ }^{2}$ Примітка. Про С. Оріховського та український складник його світогляду див. спеціальний розділ академічної історії української літератури авторства М. Трофимука: Iсторія української літератури, том перший. Давня література (X-nерша пол. XVI cm.), наук. ред. Ю. Пелешенко, М. Сулима, Київ 2013, с. 722-728. 
Були перші дні цьогорічного травня - місяця „синьої туги й юного божевілля" 3 Ц Ці слова Юрія Косача спливли в пам'яті мимохіть, бо ж голова затуманилася від запаху завчасу розквітлих білосніжних акацій, магічної краси стародавнього міста... Міста без трамваїв, автобусів - відлік часу тут іде згідно із унікальним - 31344 року — астрономічним годинником, що нині на вежі збудованого пізніше у 1599-1605 роках, Палаццо дель Капітаніо.

Оздобою художньої школи із XIV століття є дивовижні фрески, на яких можна побачити портрет безсмертного Петрарки. А ботанічний сад 31585 (!) року до сьогодні плекає пальму, під якою в 1786 році стояв у задумі великий Гете... Та понад усі очікування — збудована Енріко Скровені (Scrovegnich) в 1303-му так звана „Каплиця Скровені”.

У 1303-1305 pp. Джотто (Giotto, 1267(?) -1337) намалював фрески зі сценами із життя Христа. На одній із них спортретований Скровені оферує до рук Божої Матері модель святої каплиці.

I не повірилося власним очам, коли в один із тих незабутніх травневих вечорів у самому центрі Падуї, із новочасної вітрини магазину „Niju-niju” на вулиці Гарібальді в самісіньку душу зазирнули жіночі й чоловічі українські вишиванки. Стародавній світ, колиска європейськї цивілізації з тієї миті почала промовляти пам'яттю спільної праісторії, таємничі коди якої відчитуються, часом навіть усупереч власній волі, але тільки серцем.

Містична Венеція. Ї̈і історія сягає сивих часів, а найдавніший легендарний відгомін - Гомерової „Іліади”, саме того місця, де Гомер згадує про Енетів, які поспішають із Пафлагоніїі, аби врятувати Пріама. Залишивши свою землю, Енети оселилися на здобутих силою теренах і заснували там місто Альтін, звідки вирушили на острів Торчелло. 3 того часу започатковується понад тисячолітня історія Сереніссіми - Найяснішої Венецької Республіки. Великого Дива біля узбережжя Адріатичного моря. 3840 року, здобувши незалежність від Візантії, Венеція починає домінувати над Адріатикою.

Так розпочиналися століття великої історії, позначеної досягненнями мистецтва, архітектури, інженерної справи, філософії, літератури. I, як то буває в історії, після піку слави - великий занепад після війни з Туреччиною в 1714 1718 роках. Найстрашнішим, власне фатальним, став 1797 рік: саме тоді інвазія французьких військ довершила остаточне падіння Сереніссіми.

Тут усе вражає. Що найбільше? Очевидно, оригінальні полотна художників світової слави. Найуславленішого митця своєї епохи Тиціана (під таким іменем увійшов до історії Тізіано Вецелліо (1485-1576), який прожив 90 років і малював до останнього дня. Це саме його пензлю належать портрети найвидатніших особистостей доби.

Шістдесят років земного життя відміряла доля Веронезе (Паоло Каліарі, 1528-1588). Митець надавав перевагу історичним та міфологічним сценам, працюючи для заможної венецької аристократії. Упродовж кількох віків продовжує надихати життєствердний дух його мистецтва, його незвична кольористика, характеристична барва, передусім і зокрема уславлена „зелень Веронезе”.

Чи Вітторе Kapnaччіo (1455-1526) із його відчуттям екзотичних деталей, якому вдалося поєднати гідну ілюстратора увагу до окремих штрихів, відчуття тих деталей із залюбленістю в монументальний простір ${ }^{4}$. Значна частина його

${ }^{3}$ Ю. Косач, Чорна пані та інші оповідання, Накладом видавничої спілки „Нові шляхи”, Львів 1931, с. 8.

${ }^{4}$ Wenecja - udany weekend (tytuł oryginału — La Guida Verde. Venezia), red. Prowadzący A. Moncznik, Kraków 2007, s. 44. 
полотен — це пейзажі, у яких дуже точно зображене неймовірне розмаїття світів фауни і флори.

А геніальний митець Якопо Робусті, відомий у світі як Тінторетто (15181594), зумів виробити неповторну творчу манеру: зображуючи переважно релігійні сюжети, досягнув неповторних ефектів у передачі світлотіней, що дають його творам враження фосфоризації. Одним із найкращих його шедеврів $є$ полотно „Чуда святого Марка”.

Святий Марко. Чим Палац Дожів є серед світських будинків Венеції, тим і костел святого Марка є серед святинь. У цьому переконують читача довідники ${ }^{5}$. Базиліка Святого Марка є незрівнянна у своїй красі, вона сяє золотом, мармуром та мозаїками. Дивує велич казкового багатства (утім, також і награбованого), а також поєднання різних стилів у будові: все разом створює потужну силу краси й величі, гідної подиву й захвату.

Власне, це дожа Андрій Дондоло (панував 1342-1354 рр.), який був і видатним венецьким писарем. У своїй хроніці він розповів, що останки святого євангеліста Марка 828 року було перенесено до Венеції з Сгипетської Александрії.

Дожа Юстиніан заповів фундуш на будову костелу св. Марка. І такий храм постає. Спочатку переважно дерев’яний (упродовж 830-864рр.). Постає, власне, та саме тому місці, де раніше стояв костел першого патрона Венеції св. Теодора, який було збудовано ще 532 року. 976 року була велика пожежа, у якій згорів і костел, і палац дожів, і ще інші два костели та 300 будинків Венеції. Та вже того ж самому 976 року було розпочато відбудову нового костелу, яку успішно завершили 1008 року.

Але тільки за панування дожі Домініка Контаріні в перш. пол. XI ст. храм святого Марка набув свого сьогоднішнього вигляду, а 8 жовтня 1085 року він був посвячений.

Палац Дожів - то наступне диво й разючий контраст. Небаченої пишноти й багатства палац, але в його бездонних підвалах — найжорстокіша в'язниця, по дорозі до якої приречені, по дорозі в оте моторошне й сьогодні підземелля, переходячи через „міст зітхань”, могли востаннє побачити свою незрівнянну й кохану Венецію:

Na moście Westchnień w Wenecji stałem,

Skąd w lewo pałac, a w prawo więzienie;

Z wody półkolem wystrzela wspaniałem

Gród, jak na różdżki czarownej skinienie.

Tysiąc lat w mglistym obrazie tu staje;

Zamarła sława śle uśmiech z mogiły

Odległym wiekom, - gdy podbite kraje

Lwu skrzydlatemu daninę znosiły;

Kiedy Wenecja w stu wysep koronie

$\mathrm{Na}$ swoim władnym zasiadała tronie... ${ }^{6}$.

Жодна поезія, утім, не в силі передати того почуття, яке мали в душі приречені. А метафоричний міст зітхань моєї України за Італією - дивовижною країною, мова якої така ж співуча й мелодійна, як наша українська.

${ }^{5}$ L. Sternklar, Artystyczno-informacyjny przewodnik po Wenecji $i$ wyspach okolicznych z planem miasta, Lwów-Warszawa 1903, s. 102.

${ }^{6}$ L. Byron, Wędrówki Childe-Harolda, poemat, pieśń IV, przekład A. Krajeńskiego, cyt. za: L. Sternklar, Artystyczno-informatyczny przewodnik po Wenecji i wyspach okolicznych z planem miasta, z drukarni słowa polskiego we Lwowie pod zarządem J. Ziembińskiego, Lwów 1903, s. 94. 
У Венеції міг би бути (!) такий собі скромний будинок понад самісіньким $\mathrm{pio}^{7}$, на фронтоні якого так природньо (як десятки інших) виглядав би надпис: тут у XIX ст. перебував великий український поет Тарас Шевченко. Бо ж, власне, саме до Італії мав твердий намір їхати й студіювати високе мистецтво наш Кобзар, а потрапив з волі царя на 10 років заслання.

Найрозкішнішим витвором (а водночас і найбільш промовистим прикладом венецької тенденції до тріумфального монументалізму!) тут уважають костел під назвою „Свята Марія делла Салюте” (S. Maria della Salute). Архітектором цього шедевру $є$ той самий творець, який $є$ й автором найгарніших барокових палаців понад Каналом Гранде (Canal Grande) - Бальтазар Лонгена (Baldassarre Longhena, 1598-1682). Костел „Свята Марія делла Салюте” - це біла сильветка, потужні сходи й чарівний портик, а ще - чисельні ангели й пророки дивовижної краси...

Балансування поміж минулим та новочасним понад усяку міру виснажило й саму Венецію, і ії корінних мешканців, а їхня толерантність та „терплячість до десидентів", а ще до неймовірно великої кількості туристів, очевидно, вичерпається. I то, власне, не панацея, що саме туристи тут нині $€$ джерелом чималих заробітків ${ }^{8}$.

Сьогодні Венеція волає про допомогу. Небаченої досі висоти хвиля в 1916-му, а не тільки бомбардування в роки першої світової війни принесли їй лихо та велику шкоду. Науковці наголошують на зростаючому рівні морської води за одночасного осідання окремих фрагментів земної кори. Ризик зникнення Венеції при поступовому іiі обезлюдненні нині дуже значний.

Але не потрібні нам асоціації зі змістом оповідання Томаса Манна „Смерть у Венеції”, у якому автор чи не століття тому зобразив Сереніссіму в стані тотального занепаду й розкладу: герой твору німецький письменник Густав фон Ашенбах стає свідком епідемії холери.

Авторці цього есе імпонує життєствердно-карнавальний дискурс Юрія Андруховича, за яким незбагненна сила не лише венецьких традицій, а й, безперечно, українського родоводу. Так само Ю. Андрухович у „Перверзії” тонко й точно відчув і передав оту (лише наприкінці XX ст. $з$ великою помпою відроджену) пристрасть до жартів, маскарадів, незліченного розмаїття масок. Маска Стаса Перфецького у карнавальному сценарії Юрія Андруховича $є$ посланням у часі від козака-характерника - одного з тих сміливців, до яких венецький посол Сангредо послав дипломата (водночас поета і священика) Альберто Віміну (Мікеле Б'янкі, 1603 - 1667) з метою зібрати відомості про Військо Запорізьке, але й провести переговори щодо організації козацьких походів проти Туреччини ${ }^{9}$, тобто він шукав підтримки для Венеції.

Сьогодні новочасний карнавал у Венеції розпочинається символічнознаковим, дивовижно-прекрасним дійством „volo del'angelo”, що означає „політ ангела". I хоч у ролі ангела виступає щоразу відважніший каскадер-акробат, який на спеціальних линвах ,злітає” із самісінької дзвіниці базиліки святого Марка, а завершує свій лет на даху величного Палацу Дожів, — люди ніколи не перестануть вірити в казку. Карнавал - чарівна казка, однак це не лише свя-

${ }^{7}$ Примітка. Ріo (rio) — так у Венеції називаються чисельні відгалуження каналів. Властиво каналів як таких є тільки три: Canal Grande, Canale della Giudecca, Canale di Canareggioю. Переважна більшість венеційських „вулиць”- то саме pio.

${ }^{8}$ Wenecja - udany weekend (tytuł oryginału - La Guida Verde. Venezia), red. prowadzacy A. Moncznik, Kraków 2007, s. 51.

9 Див.: http://www.history.org.ua/?termin=Vimina. (доступ 20.06.2015). 
то $з$ вражаючим видовищем, а це ще й народження нового світу замість того, що віджив.

Про карнавал, що нині став об'єктом інтердисциплінарних і міжнародних студій, сказано й написано багато. Близько 3500 томів ${ }^{10}$ налічує європейська бібліотека карнавалу, що розміщена в спеціальному Музеї карнавалу й маски в містечку Бінче (Binche) ${ }^{11}$ в Бельгіï (Musée International du Carnaval et du Masque). Сьогодні поняття „карнавальна бібліотека” входить до активного наукового обігу, а, напр., у Німеччині розвивається й плекається навіть окрема етнологічна субдисципліна під назвою „Fastnachtsforschung”, що означає дослідження карнавалу. В амбівалентному карнавальному дійстві присутній, однак, аспект очисних креативних змін, у ритмі яких невпинно живе й оновлюється людство. Вичерпується старий час, в горнилі його гартується новий світ. Твориться і новий український час. I новий український світ.

${ }^{10}$ W. Dudzik, Wstęp, [w:] Karnawat. Studia historyczno-antropologiczne, red. W. Dudzik, Warszawa 2011, s. 7.

${ }^{11}$ Примітка. За рішенням ЮНЕСКО містечко Бінче, у якому проводять один з найцікавіших карнавалів Європи, вписане в перелік нематеріальної спадщини людства. 